\title{
- КОНЦЕПТУАЛІЗАЦІЯ ФЕНОМЕНІВ «ВІЙНИ» ТА «МИРУ»: ЕТИКО-КУЛЬТУРНИЙ ВИМІР
}

\section{- Чуприна Юлія Віталіївна}

\section{Аспірантка,} ORCID: 0000-0003-4893-7313, e-mail: julie.chupryna@gmail.com, Київський національний університет культури і мистецтв, вул. Є. Коновальця, 36, Київ, Україна, 01133

\section{- Для цитування:}

Чуприна, Ю.В. (2021). Концептуалізація феноменів «війни» та «миру»: етико-культурний вимір. Питання культурології, (38), 216-225. doi: https://doi.org/10.31866/24101311.38.2021.245954.

\section{Анотація}

Явища війни та миру мають особливе значення у глобалізованому світі, де межа переходу цих феноменів почасти ілюзорна і набуває все більших гібридних форм. Особливо гостро постає невирішеність мікроконфрліктів, що часто призводить до збройного протистояння. Тому актуальності набувають вивчення та розуміння культурної обумовленостівійськовоїприроди, завдякичому можназапобігтитаким загрозам. Метастатті полягає у дослідженні явищ війни та миру в межах етико-культурних практик. Методологія дослідження визначається комплексним використанням інструментарію культурології як науки щодо специфріки феноменів війни та миру. Основу дослідження становлять аналітико-описовий, порівняльно-історичний, компаративістський методи, а також методи класифікацій та екстраполяції для вивчення еволюції понять війни та миру, проєктування та теоретичного осмислення основних концепцій, що дозволяють простежити важливість переходу від «культури війни» до «культури миру». Наукова новизна - здійснено аналіз не лише феноменів війни та миру, а й простежено парадигмальні відмінності в концептуалізації відповідних понять. Особлива увага була приділена культивуванню мирних практик, що виступають як дійові засоби протидії поширення мілітаризованого світогляду. Висновки. Визначено, що в сучасному світі надзвичайно важливими $є$ культивування та збереження знань про мир і впровадження необхідних заходів для стабілізації світопорядку. Розуміння сенсу війни та миру як фракту культури дозволяє вибудувати теоретико-методологічне і практичне підґрунтя вирішення проблем діалогу культур, дихотомії «війна-культура» та «культура-мир», дослідити взаємозумовленість і взаємоузгодженість із психологічними, соціологічними, політичними та фрілософськими чинниками, а також особливу увагу сфокусувати на комплексі мирних практик, що покликаний змінити парадигму «культури війни». Доведено, що побудова стабільного світопорядку міститься не лише у зовнішньо обумовлених факторах, а насамперед у власній життєвій позиції та незаангажованості. 
Рівень критичного мислення має повернути гуманістичний світогляд та привернути увагу до загрози військових протистоянь.

Ключові слова: війна; культура; мир; діалог культур

\section{Вступ}

У сучасному світі війна більше не розуміється як засіб чи інструмент досягнення певних цілей, а виступає метаморфозою сили і поступово трансформується від стратегічної єдності до тактичної фррагментарності. У цьому аспекті ключового значення набуває поняття миру, яке поступово перетворюється на дійову практику, засновану на багатовікових культурно-історичних доробках. У глобалізованому світі явища війни та миру мають особливе значення, де межа переходу цих френоменів почасти ілюзорна і все більше набуває гібридних форм. Особливо гостро постає невирішеність мікроконфліктів, що часто призводить до збройного протистояння на макрорівні. Глобальна криза цінностей та нівелювання гуманності повертає необхідність актуальності проблеми військового та мирного, а також продукування мирних сенсів на противагу поширенню мілітаризованої культури, і саме за допомогою розуміння культурної обумовленості військової природи можна запобігти воєнним загрозам.

Дослідженням явищ війни та миру за допомогою етико-культурних вимірів займались такі науковці, як: Р. Арон, М. Бердяєв, А. Гусейнов та Р. Апресян (1998), А. Дирін та В. Кузін (Дырин \& Кузин, 1992), І. Кант, В. Малиновський, К. Райн, Д. Рогозін та ін. Важливим інформаційним джерелом для теми дослідження стали теоретична та практична спадщина ЮНЕСКО, а також дослідників феномену миру, серед яких виділимо Е. Боулдінг (Boulding, 1988, 2000), Й. Галтунга, Б. Рейрдон, А. Швейцер (1992). Наголосимо, що Е. Боулдінг стала однією із перших дослідниць, яка почала активно вивчати та впроваджувати освіту у сорері миру. Проте саме трансформаційний аспект явищ війни та миру у межах культурно-історичної динаміки понять розроблений недостатньо, що й зумовлюється актуалізацією цієї теми.

\section{- Мета статті}

Мета статті полягає у дослідженні явищ війни та миру в межах етико-культурних практик. Завданнями є: сорормувати характерні риси концепцій «культури війни» та «культури миру»; розкрити сутність явища миру через призму історичної динаміки; дослідити чинники та засоби формування мирного та військового способу мислення, їхнього впливу на ескалацію військових ситуацій. Наукова новизна - здійснено аналіз не лише феноменів війни та миру, а й простежено парадигмальні відмінності в концептуалізації відповідних понять. Особлива увага була приділена культивуванню мирних практик, що виступають як дійові засоби протидії поширення мілітаризованого світогляду.

\section{- Виклад матеріалу дослідження}

Наприкінці XX ст. ЮНЕСКО затвердила програму «На шляху до культури миру», яка була покликана забезпечити мирне врегулювання конфліктів, посла- 
бити міжетнічні та міжрелігійні сутички, налагодити культуру діалогу та взаєморозуміння (Creveld van, 1991). Проте для реалізації цієї мети потрібно замінити концепт «культури війни», домінувати його на концепцію «культури миру». Зазначимо, що поняття «культура війни» $є$ багатогранним та історично детермінованим (Ротердамський, 1993). Культура війни - дискурсивне явище, яке передбачає заміщення загальносоціальних переконань і цінностей у необхідних напрямках засобами пропаганди із метою легітимізації сили та впровадження мілітаризованого світогляду.

Концептуалізація поняття війни відбувалась у кількох вимірах:

- фрілософському (війна як особливе явище цивілізації, що конфрігурує світовий порядок);

- соціально-культурному (війна як ситуація соціального конфлікту, де задіяні не лише насильницькі методи, а й методи суспільного діалогу та розгляду соціальних змін);

- військово-політичному (війна як спосіб досягнення політичних цілей);

- психологічному (війна як вроджені агресивні початки людини, фоормування дихотомій «свій-чужий», «герой-ворог»);

- технічному (війна як використання технічних потужностей) (Creveld van, 1991).

Проте безпосереднє термінологічне розуміння війни може розглядатись як дія, що скоєна із грубим порушенням міжнародного права, застосування агресії та насилля, а також як така, що виконує захисну функцію, чи є справедливо обумовленою, чи виступає засобом припинення інших воєнних дій. Крім того, із морально-етичного боку розглядаються такі якості, як героїзм, відвага, виявлення патріотизму, і на противагу - агресія, загарбництво, насильницьке вторгнення. Тому здійснення переходу від «культури війни» до «культури миру» $€$ вирішальним кроком до врегулювання конфліктогенних ситуацій стабільності світопорядку.

«Культура миру» - це насамперед концепція, у якій мир розглядається як динамічний баланс, що охоплює соціальні, політичні та культурні фрактори. Проте для досягнення мирного стану потрібно прикласти набагато більше зусиль, ніж для початку збройного насильства, зокрема, на думку Б. Шоу, мир - не лише кращий, а й надзвичайно складніший за війну (Lynn, 2003). Ще однією важливою характеристикою виступає добровільність, оскільки культура миру не може бути нав'язана, а є процесом, що розвивається на основі переконань і дій кожного окремого члена соціуму. У цьому аспекті головним стає «внутрішній мир» суспільства як стану, що позбавлений не лише збройного, а й інших форм насильства (Гусейнов \& Апресян, 1998).

Для досягнення вищезазначених цілей можна використати наступні методи:

1) на противагу фрормуванню образу ворога, розвивати взаєморозуміння, солідарність і толерантність; тію;

2) на противагу авторитарним формам правління, застосовувати демокра-

3) на противагу пропаганді, використовувати вільний потік інформації та доступ до поширення знань; 
4) на противагу домінуванню чоловіків, надавати рівність як чоловікам, так і жінкам;

5) на противагу експлуатації навколишнього середовища, застосовувати концепції сталого розвитку та соціального вдосконалення;

6) на противагу збільшенню кількості військової техніки та військового складу, втілювати поступове роззброєння;

7) на противагу знаходження ворогів та дегуманізації, здійснювати кооперацію та будувати комунітарні спільноти;

8) на противагу поширенню образу насильства, використовувати повагу як основний чинник гармонійного співіснування;

9) на противагу продукування страху та залякування, будувати систему захисту осіб;

10) на противагу розповсюдженню знань про війну, надавати знання про мир (Boulding, 2000).

Наразі у сфрері міжнародної освіти впроваджуються безкоштовні онлайнкурси з досягнення сталого розвитку, протидії насильству та більш ґрунтовного вивчення поняття миру. При цьому дослідники наголошують на такі упередження та розповсюджені твердження суспільної думки, як: якщо хочеш миру готуйся до війни, ніщо не може змінитись, оскільки насильство є невід'ємною частиною людського характеру, або насильство $€$ найдійовішим способом вирішення конфлікту і т. ін. Тому не дивно, що такого роду переконання суттєво впливають на мілітаризацію зовнішнього та внутрішнього життя суспільства. Ментальний настрій також відіграє неабияку роль у культурній сфері, адже поширення насильницької лексики, пропагування подібних сцен у кінематографі та постійне розповсюдження медійними засобами є тими кроками, які сприяють культурі війни міцно вкорінюватись та сіяти негативні наслідки.

Отже, варто пам'ятати, що культура миру означає мир не лише як відсутність збройних конфліктів чи війни, але й зосереджується на змісті та умовах миру. Для досягнення мирного стану потрібно залучати всі наявні суспільні ресурси, розгортати громадський діалог, а також знаходити шляхи до взаєморозуміння та співпраці. Сьогоденний виклик полягає в тому, щоб знайти шляхи подолати пасивний стан людства, апатичний дегуманізм та соціокультурну деструкцію, втілити перехід від сили до розуму, від конфліктів та насильства до діалогу та миру. Як вдало зауважив Джон Кеннеді, мир - щоденний, щотижневий, щомісячний процес, який поступово змінює думки, повільно розмиває старі бар'єри, спокійно будує нові структури (Cassidy, 2006).

Ідея про мир, культивування та збереження гармонійних відносин у суспільстві, які ведуть до створення внутрішньої духовної рівноваги кожної окремої особистості, з'явилася ще в період античності. Проте переважна більшість фрілософрів наголошували на невід'ємності понять війна-мир і розглядали ці два явища сукупно. Філософська традиція осмислення феномену війни, як правило, пов'язана з вивченням війни на фоні загальнофілософських проблем. Давньогрецькі фрілософри (Арістотель, Геракліт, Демокріт, Платон) зробили значний внесок в аналіз соціальної природи війни. Для Геракліта війна виступає як мати всіх речей (Дырин \& Кузин, 1992). Демокріт одним із перших поставив питання 
про походження війни, зазначивши серед ї̈ причин майнову нерівність людей, внутрішньодержавне свавілля та збільшення бідності громадян. Сократ у ряді причин війни називав: недосконалість людини; неможливість людей розібратися в сенсі добра і зла; порушення законності в державі з волі правителів. Платон визначив війну як «частину мистецтва політичного»: війна виступає метою і однією з основ становлення рабовласницької державності, політичним законом iї розвитку. Право сильного над слабким, на думку Платона (2018), є чільним принципом соціального розвитку. В органічному взаємозв'язку з політикою та іншими сторонами суспільного життя розглядає війну також Арістотель, звертаючи увагу на основні сторони ії змісту, насамперед цілі, переслідувані збройним насильством; і безпосередньо збройну боротьбу. Саме роздуми античних фрілософів багато в чому визначили ту область, в рамках якої розглядалася проблема війни-миру.

Низка воєн веде до надлому, який, збільшуючись, переходить у розпад. Згубна концентрація всіх сил на братовбивчій війні породжує військовий психоз, здатний впливати на різні аспекти життя суспільства. Однак війна може також стимулювати розвиток техніки, а отже, сприяти поглибленню наших знань про закони матеріального світу. Оскільки рівень людського процвітання зазвичай оцінюють за масштабами влади і багатства, часто виявляється так, що історія трагічного суспільного занепаду в народній свідомості сприймається як періоди дивовижного зльоту та процвітання. Ця сумна омана може тривати протягом багатьох століть. Проте рано чи пізно це проходить. Прозріння настає, коли суспільство починає війну проти самого себе. Ця війна поглинає ресурси, виснажує життєві сили. Суспільство починає пожирати само себе (Гроций, 2020).

Для зміни мілітаризованого вектора на сучасному етапі впроваджується навчання у галузі миру, що розглядається і як філософрія, і як процес, що включає навички, які використовують елементи аудіювання, рефрлексії, вирішення проблем, співпраці та подолання конфрліктів. Такий процес допомагає людям створювати безпечний світ і будувати стійке середовище. Зокрема, філософрія миру вчить ненасильству, любові, співчуттю і повазі до всього живого. Міжнародна комісія освіти з питань миру та Асоціація досліджень миру використовують як експліцитні, так і імпліцитні чинники для досягнення поставленої мети. Експліцитна освіта традиційно пов'язана з дослідженнями в галузі миру - обробкою фактів, виявлених у результаті досліджень питань миру. Імпліцитна освіта у сфрері миру - це спроба створення культури миру та процесу ознайомлення та засвоєння ії особами, які навчаються. Бетті Рейрдон наголошує на тому, що найбільш повне визначення освіти у сфері миру та обговорення мети миру полягає у поширенні інформації про те, що освіта необхідна людству для розвитку свідомості, а це, зі свого боку, створить умови для зміни соціальних структур і моделей мислення (Luttwak, 2002). Рейрдон вважає, що в центрі повинен міститись потенціал для майбутніх трансформацій, які будуть здійснені як всередині, так і назовні.

Також варто зауважити, що ЮНЕСКО (UNESCO, 1981) визначила такий тип освіти у сфері миру, як «міжнародну за своєю природою, глобальну в перспективі та діє-орієнтовану у прагненнях». 
Питаннями освіти у сфрері миру займались соціальні реформатори ще у XIX ст., такі як Джейн Аддамс і Фенні Ферн Ендрюс. Аддамс була однією із перших, хто встановив зв'язок між соціальними умовами, що лежать в основі пригноблення жінок, та пропагандою насильства у спільнотах по всьому світу. Згодом ідеї щодо всесвітньої освіти з питань миру, включаючи ії реляційний та трансформаційний потенціал, частково виникли внаслідок жіночих рухів та їхнього впливу на сфреру досліджень миру. Феміністки були стурбовані навчанням у сфрері миру, де значною мірою домінували чоловіки, а також поширенням технічних аспектів гонки озброєнь, зневаги до наслідків насильства.

У сучасному ж розумінні дослідження у сфрері миру розпочалися після Другої світової війни за рахунок створення різноманітних дослідницьких інститутів для вивчення миру. У цей же період проходять й мирні рухи (1940-ві - 1950-ті роки). При цьому така освіта розглядалась як пропаганда початкових мирних концепцій.

Один із перших закладів був створений Йоханом Галтунгом в Осло наприкінці 50-х років XXст. Ці інститути були засновані як незалежні структури, оскільки пошук університетів, які б підтримали такі проєкти, виявився практично неможливим. Отже, уже в 1965 році заснована Елізою та Кеннетом Боулдінг Міжнародна асоціація досліджень миру, яка стала результатом роботи квакерів та жінок Міжнародної ліги за мир та свободу, отримала фрінансування від ЮНЕСКО. Інститут у сфрері дослідження миру був заснований для вивчення явища війни, її причин і способів ії подолання.

Перші науковці, які вивчали культуру миру, визнавали залежну взаємодію між дослідженням миру, освітою та громадянською активністю. Еліза Боулдінг (Boulding, 1988) у своїх творах часто використовувала таку взаємозалежну метафоричність. Учена вважала, що дослідження миру та мирних дій метафорично пов'язані з медичною освітою та практикою. Враховуючи, що лікарі навчаються лікувати пацієнтів, люди, які вивчають сферу миру, намагаються зцілити світ. Боулдінг по суті не робить різниці між важливістю мирного дослідження, освіти та дій. Боулдінг наголошувала на тому, що її мета - ініціювати діалог між громадською діяльністю та дослідженнями перспективи вивчення питання миру. А її роль - посередницька між мирними активістами і дослідниками миру, кожен із яких вважає, що інший не спроможний вирішувати потреби реалій. Зі створенням COPRED (Консорціуму з питань миру, досліджень, освіти та розвитку) в 1970-ті роки Боулдінг висловила бажання об'єднати ці несумісні елементи.

У 1960-х роках існувала інтенсивна дискусія про зв'язок між питаннями миру та феміністичними проблеми. Водночас деякі феміністки розглядали дослідження миру як «виток», кінцева мета якого надасть визволення від гнітючих структур. Міжнародна жіноча ліга за мир та свободу вкотре наголошувала на застосуванні пацифрізму до наростаючих жіночих рухів (Boulding, 2000). Дослідження виявили чіткі зв'язки між бідністю, расизмом, дітьми, екологічною небезпекою та фрізичним, структурним і психологічним насильством. Мир розглядався як стан гармонійних відносин, зокрема внутрішньоособистих, міжособистих та міжгалузевих. 
На сьогодні до системи освіти у сфрері миру входять наступні напрями:

- освіта у сфрері захисту людських прав,

- освіта про навколишнє середовище,

- освіта у сфері зовнішніх відносин,

- освіта розвитку,

- освіта у сфері вирішення конфліктів.

Також важливою ланкою у сфері вивчення миру є дослідження явища війни та супровідної літератури. Лише таким чином, на думку багатьох дослідників, можна повернути гуманістичний світогляд та привернути увагу до загрози військових протистоянь.

\section{- Висновки}

Отже, побудова стабільного світопорядку міститься не лише у зовнішньо обумовлених фракторах, а передусім у власній життєвій позиції та незаангажованості. Рівень критичного мислення має виховуватись та ставати ключовою рисою в питаннях розрізнення впливу мілітаризованої культури та побудови «культури миру». На сьогодні надзвичайно важливим $є$ культивування та збереження знань про мир та впровадження необхідних заходів для стабілізації світопорядку. Усвідомлюючи рівень критичності та нестабільності, які побутують у світі, людство має взяти на себе відповідальність та відвагу за пошуки мирних рішень конфрліктів, підтримувати та заохочувати сталий розвиток, заощаджувати ресурси, активно послуговуватись «мирним» лексиконом і всіма можливими діями змушувати війну та насилля застарівати та активно відроджувати МИР.

\section{- Список використаних джерел}

Гроций, Г. (2020). О праве войны и мира. Центр навчальної літератури.

Гусейнов, А. А., \& Апресян, Р. Г. (1998). Этика. Гардарика.

Дырин, А. И., \& Кузин, В. П. (1992). Проблемы войны и мира в социально-фрилософрской мысли античности [Монография]. Гуманитарная академия Вооруженных сил.

Платон, (2018). Государство. Азбука.

Ротердамський, Е. (1993). Похвала Глупоті. Домашні бесіди. Основи.

Швейцер, А. (1992). Благоговение перед жизнью. Прогресс.

Boulding, E. (1988). Building a Global Civic Culture: Education for an Interdependent World. Teachers College Press.

Boulding, E. (2000). Cultures of Peace: The Hidden Side of History. Syracuse University Press.

Cassidy, R. M. (2006). Counterinsurgency and the Global War on Terror: Military Culture and Irregular War. Praeger.

Creveld van, M. (1991). The Transformation of War: The Most Radical Reinterpretation of Armed Conflict Since Clausewitz. Free Press.

Luttwak, E. N. (2002). Strategy: The Logic of War and Peace. Belknap Press

Lynn, J. (2003). Battle: A History of Combat and Culture From Ancient Greece to Modern America. Westview Press.

UNESCO. (1981). UNESCO Yearbook on Peace and Conflict Studies. Greenwood Press. 


\section{- References}

Boulding, E. (1988). Building a Global Civic Culture: Education for an Interdependent World.

Teachers College Press [in English].

Boulding, E. (2000). Cultures of Peace: The Hidden Side of History. Syracuse University Press [in English].

Cassidy, R. M. (2006). Counterinsurgency and the Global War on Terror: Military Culture and Irregular War. Praeger [in English].

Creveld van, M. (1991). The Transformation of War: The Most Radical Reinterpretation of Armed Conflict Since Clausewitz. Free Press [in English].

Dyrin, A. I., \& Kuzin, V. P. (1992). Problemy voiny i mira v sotcialno-filosofskoi mysli antichnosti [Problems of War and Peace in the Socio-philosophical Thought of Antiquity] [Monograph]. Gumanitarnaia akademiia Vooruzhennykh sil [in Russian].

Groot, H. (2020). O prave voiny i mira [On the Law of War and Peace]. Tsentr navchalnoi literatury [in Russian].

Guseinov, A. A., \& Apresian, R. G. (1998). Etika [Ethics]. Gardarika [in Russian].

Luttwak, E. N. (2002). Strategy: The Logic of War and Peace. Belknap Press [in English].

Lynn, J. (2003). Battle: A History of Combat and Culture From Ancient Greece to Modern America. Westview Press [in English].

Plato, (2018). Gosudarstvo [State]. Azbuka [in Russian].

Roterodamus, E. (1993). Pokhvala Hlupoti. Domashni besidy [Praise of Folly. Home Conversations]. Osnovy [in Ukrainian].

Shveitcer, A. (1992). Blagogovenie pered zhizniu [Reverence in Front of Life]. Progress [in Russian].

UNESCO. (1981). UNESCO Yearbook on Peace and Conflict Studies. Greenwood Press [in English].

\section{- CONCEPTUALISATION OF THE PHENOMENA OF "WAR" AND "PEACE”: ETHICAL AND CULTURAL DIMENSIONS}

\section{- Yuliia Chupryna}

- PhD student,

ORCID: 0000-0003-4893-7313, e-mail: julie.chupryna@gmail.com,

Kyiv National University of Culture and Arts,

Kyiv, Ukraine

\section{Abstract}

The phenomena of war and peace are becoming particularly important in a globalised world, where the boundary of the transition of these phenomena is partly illusory and is acquiring the ever-larger hybrid forms. The unresolved micro-conflicts are especially acute, which often leads to armed confrontation. Therefore, it is important to study and understand the cultural conditionality of the military nature so, that such threats can be prevented. The purpose of the article is to study the phenomena of war and peace within the framework of ethical and cultural practices. The research methodology is determined by the complex use of 
culturology tools as a science on the special features of the phenomena of war and peace. The research is based on the analytical and descriptive, comparative and historical methods, as well as the methods of classification and extrapolation to study the evolution of the concepts of war and peace, projecting and theoretical understanding of the main concepts that allow us to trace the importance of the transition from a "culture of war" to a "culture of peace". Scientific novelty. The article not only provides an analysis of the phenomena of war and peace but also demonstrates paradigmatic differences in the conceptualisation of the corresponding concepts. Particular attention is paid to the cultivation of peaceful practices that act as effective means of countering the spread of a militarised worldview. Conclusions. It is determined that in the modern world it is extremely important to cultivate and preserve knowledge about peace and implement the necessary measures to stabilise the world order. Understanding the meaning of war and peace as a fact of culture allows us to build a theoretical, methodological, and practical basis for solving the issues of intercultural dialogue, the dichotomy "war-culture" and "culture-peace", to study the interdependence and mutual coherence with psychological, sociological, political and philosophical factors, as well as to focus special attention on a set of peaceful practices designed to change the paradigm of "war culture". It is proved that the construction of a stable world order is contained not only in externally determined factors, but, first of all, in one's own life position and non-bias. The level of critical thinking should bring back a humanistic worldview and draw attention to the threat of military confrontations.

Keywords: war; culture; peace; dialogue of cultures

\title{
КОНЦЕПТУАЛИЗАЦИЯ ФЕНОМЕНОВ «ВОЙНЫ» И «МИРА»: ЭТИКО-КУЛЬТУРНОЕ ИЗМЕРЕНИЕ
}

\author{
Чуприна Юлия Витальевна \\ Аспирантка, \\ ORCID: 0000-0003-4893-7313, e-mail: julie.chupryna@gmail.com, \\ Киевский национальный университет культуры и искусств, \\ Киев, Украина
}

\section{Аннотация}

Явления войны и мира приобретают особое значение в глобальном мире, где граница перехода данных френоменов отчасти иллюзорна и приобретает все большие гибридные фрормы. Особенно остро стоит нерешенность микроконфрликтов, что часто приводит к вооруженному противостоянию. Поэтому актуальность приобретают изучение и понимание культурной обусловленности военной природы, благодаря чему можно предотвратить такие угрозы. Цель статьи заключается в исследовании явлений войны и мира в пределах этико-культурных практик. Методология исследования определяется комплексным использованием инструментария культурологии как науки о специфике феноменов войны и мира. Основу исследования составляют аналитикоописательный, сравнительно-исторический, компаративистский методы, а также методы классификации и экстраполяции для изучения эволюции понятий войны и мира, 
проектирования и теоретического осмысления основных концепций, позволяющих проследить важность перехода от «культуры войны» до «культуры мира». Научная новизна - осуществлен анализ не только феноменов войны и мира, но и прослежены парадигмальные различия в концептуализации соответствующих понятий. Особое внимание было уделено культивированию мирных практик, выступающих как действенные средства противодействия распространения милитаризированного мировоззрения. Выводы. Определено, что в современном мире чрезвычайно важно культивирование и сохранение знаний о мире и внедрение необходимых мер для стабилизации миропорядка. Понимание смысла войны и мира как факта культуры позволяет выстроить теоретико-методологическое и практическое основание решения проблем диалога культур, дихотомии «война-культура» и «культура-мир», исследовать взаимообусловленность и взаимосогласованность с психологическими, социологическими, политическими и философскими факторами, а также особое внимание сфокусировать на комплексе мирных практик, который призван изменить парадигму «культуры войны». Доказано, что построение стабильного миропорядка содержится не только во внешне обусловленных фракторах, а, в первую очередь, в собственной жизненной позиции и незаангажированности. Уровень критического мышления должен вернуть гуманистическое мировоззрение и привлечь внимание к угрозе военных противостояний.

Ключевые слова: война; культура; мир; диалог культур 